\title{
Assessment of the use of municipal and industrial wastes in agriculture
}

\author{
Czesława Jasiewicz, Jacek Antonkiewicz, Agnieszka Baran \\ Department of Agricultural Chemistry, Agricultural University in Krakow, al. Mickiewicza 21, 31-120 Krakow, Poland, \\ e-mail: rrantonk@cyfr-kr.edu.pl
}

\begin{abstract}
Agricultural usability of urban and industrial wastes was investigated in $2004-2006$ in a pot experiment carried out in the vegetation hall. In the first year of the experiment maize was the test plant, oat grass in the second and oat in the third. The experimental design comprised 11 treatments differing with fertilizer and the kind of the supplied fertilizer components. The experiment used: mineral salts, farmyard manure, compost, municipal sewage sludge and industrial sewage sludge in two fertilizer doses. Metal concentrations in the test plants were diminishing in the following direction: oat grass $>$ maize $>$ oat. The lowest concentrations of the analyzed heavy metals were assessed in the plants fertilized with farmyard manure and compost $(\mathrm{Zn}, \mathrm{Cu})$. Among the tested plants the highest quantities of $\mathrm{Zn}, \mathrm{Cu}, \mathrm{Ni}, \mathrm{Pb}$ and $\mathrm{Cd}$ were removed with the yield of the oat grass, then maize and oat. The highest uptake of $\mathrm{Zn}, \mathrm{Cu}, \mathrm{Ni}$ and $\mathrm{Pb}$ by plants was registered on a double dose of industrial sludge and $\mathrm{Cd}$ on a single dose of municipal sludge.
\end{abstract}

Keywords: heavy metals, farmyard manure compost, municipal and industrial sewage sludge.

Presented at VII Conference Wasteless Technologies and Waste Management in Chemical Industry and Agriculture, Międzyzdroje, 12 - 15 June, 2007.

\section{INTRODUCTION}

A shortage of organic fertilizers necessitates the use of wastes as unconventional fertilizers in agriculture [Mazur 1999]. Their diversified properties, depending on the kind of wastes, determine the direction of their environmental application. One of these is fertilization, soil treatment and reclamation of grounds for agricultural purposes [Baran et al 2001]. Municipal wastes contain great amounts of organic matter placing them among unconventional fertilizers, which can play an important role in soil humus balance [Czekała 1999; Mazur 2002]. Moreover, they reveal considerable differences in their chemical composition, therefore their constant inspection is very important. Diverse properties and the chemical composition of wastes often pose problems with their proper management [Grzywnowicz, Strutyński 1999]. A measure aiming at an improvement of the disadvantageous features of wastes, e.g. sludges is their composting, as a result of which the fertilizer value of wastes grows. The produced compost may be used as a fertilizer for the soil treatment or the reclamation of landfills, dumping sites or industrial waste heaps, or other degraded areas. The quality of composts originating as a result of municipal waste utilization, is therefore an important factor of their use. Composts should contain nutrients, mainly nitrogen and phosphorus necessary for plants [Chwastowska et al 1993; Gambuś, Wieczorek 1999]. Potential application of composts for agriculture is among others determined by their heavy metal concentrations which cannot exceed the allowable limits [Rozporządzenie 2002; Norma Branżowa 1989].

The investigations were conducted to assess the effect of urban and industrial wastes on the content and uptake of heavy metals by plants.

\section{MATERIAL AND METHODS}

The agricultural usability of urban and industrial wastes was investigated in $2004-2006$ in a pot experiment carried out in the vegetation hall of the Department of Agricultural Chemistry, Agricultural University in Krakow. In the first year of the experiment maize (Zea mays), San c.v. was the test plant, oat grass (Arrhenatherum elatius), Gaza c.v. in the second and oat (Avena sativa), Kasztan c.v. in the third. The experiment was conducted on the soil with the weakly loamy sand texture, $\mathrm{pH}_{\mathrm{KCl}}$ 4.66 , organic $\mathrm{C}$ content $11.2 \mathrm{~g} \cdot \mathrm{kg}^{-1}$ and very low concentrations of available phosphorus and potassium, which were respectively: $3.1 \mathrm{mg} \cdot \mathrm{kg}^{-1} \mathrm{P}$ and $14.4 \mathrm{mg} \cdot \mathrm{kg}^{-1} \mathrm{~K}$. According to the limit heavy metal concentrations the soil used for the experiment revealed the natural content of zinc $-36.65 \mathrm{mg}$; copper $-3.60 \mathrm{mg}$; nickel $-3.60 \mathrm{mg}$; lead $24.70 \mathrm{mg}$ and cadmium $-0.60 \mathrm{mg} \cdot \mathrm{kg}^{-1} \mathrm{~d} . \mathrm{m}$. [KabataPendias et al 1995].The experimental design comprised 11 treatments differing with fertilizer and the kind of the supplied fertilizer components (Tab.1). The experiment used: mineral salts, farmyard manure, compost, municipal sewage sludge and industrial sewage sludge in two fertilizer doses. Dose I was $\left(\mathrm{g} \cdot\right.$ pot $\left.^{-1}\right)$ : $55 \mathrm{~N}, 0.22 \mathrm{P}, 0.52 \mathrm{~K}$ (maize) and $0.30 \mathrm{~N}, 0.11 \mathrm{P}$ and $0.26 \mathrm{~K}$ (oat grass), and respectively for the second level: $1.10 \mathrm{~N}, 0.44 \mathrm{P}, 1.04 \mathrm{~K}$ (maize), and $0.60 \mathrm{~N}, 0.22 \mathrm{P}$ and $0.52 \mathrm{~K}$ (oat grass, oat). Mineral fertilization was applied in the form of: $\mathrm{NH}_{4} \mathrm{NO}_{3}$, $\mathrm{KH}_{2} \mathrm{PO}_{4}$ and $\mathrm{KCl}$. Organic materials were used in the first year of the experiment under maize and their doses were determined on the basis of nitrogen fertilization level [Jasiewicz, Antonkiewicz 2005]. The chemical composition of the applied fertilizer components and their doses were given in Table 2. The compost was produced of the plant wastes by Ekokonsorcjum Efekt llc enterprise in Krakow, whereas the sewage sludge originated from the urban-industrial sewage treatment plant „Empoś” in Oświęcim. The permissible norms of heavy metals were not exceeded either in the compost or in the sludges, therefore they met the requirements for the fertilizers used in agriculture and for the reclamation of soils for agronomic purposes [Regulation 2002]. 
Table 1. The chemical composition and doses of fertilizers

\begin{tabular}{|c|c|c|c|c|c|}
\hline Determination & Unit & Farmyard manure & Compost & Municipal sludge & Industrial sludge \\
\hline Dry Mass (d.m.) & $\%$ & 14.56 & 54.72 & 18.81 & 21.84 \\
\hline Organic Matter & \multirow{3}{*}{$\begin{array}{c}\mathrm{g} \cdot \mathrm{kg}^{-1} \\
\mathrm{~d} . \mathrm{m}\end{array}$} & 855.3 & 437.3 & 640.4 & 482.8 \\
\hline C-Organic & & - & 253.6 & 371.4 & 280.0 \\
\hline $\mathrm{N} / \mathrm{P} / \mathrm{K}$ & & $20.9 / 4.5 / 19.7$ & $26.4 / 5.1 / 13.4$ & $40.1 / 16.0 / 3.5$ & $28.8 / 8.6 / 2.3$ \\
\hline $\begin{array}{c}\mathrm{Zn} \\
\mathrm{Cu} \\
\mathrm{Ni} \\
\mathrm{Pb} \\
\mathrm{Cd}\end{array}$ & $\mathrm{mg} \cdot \mathrm{kg}^{-1} \mathrm{~d} . \mathrm{m}$ & $\begin{array}{r}115.0 \\
12.30 \\
1.84 \\
2.37 \\
0.69 \\
\end{array}$ & $\begin{array}{r}228.4 \\
38.25 \\
9.38 \\
16.15 \\
1.30 \\
\end{array}$ & $\begin{array}{r}741.6 \\
228.2 \\
18.23 \\
38.76 \\
2.61 \\
\end{array}$ & $\begin{array}{r}722.0 \\
797.0 \\
23.30 \\
46.25 \\
3.56 \\
\end{array}$ \\
\hline Dose for $1^{\text {st }}$ fertilization level & \multirow{2}{*}{$g \cdot \operatorname{pot}^{-1}$} & 181 & 38 & 73 & 87.45 \\
\hline Dose for $2^{\text {nd }}$ fertilization level & & 362 & 76 & 146 & 174 \\
\hline
\end{tabular}

In each year of the investigations the plant material was dried and the amount of aerial parts and roots dry mass yield was determined [Jasiewicz, Antonkiewicz 2005; Jasiewicz et al 2006]. The concentrations of $\mathrm{Zn}, \mathrm{Cu}, \mathrm{Ni}$, $\mathrm{Pb}$ and $\mathrm{Cd}$ in the plant material were assessed after the dry mineralization and ash solution in $\mathrm{HNO}_{3}$ using the ICPEAS method [Ostrowska et al 1991]. Also the uptake of the above mentioned metals by the analyzed plant species was computed. The variability coefficients were computed in order to determine the diversification in the content and uptake of the above mentioned metals. Statistical computations were made using the Statistica 7.1 programme. The significance of the differences between the compared mean concentrations of metals in the tested plants were determined by t-Student test. The analysis of variance was conducted on the significance level $\alpha \leq 0.01$.

\section{RESULTS}

The heavy metal content in the tested plants was subjected to a statistical analysis and presented as a means for the treatments (Tab.2). As results from the analysis, the differences in $\mathrm{Cd}, \mathrm{Cu}, \mathrm{Ni}, \mathrm{Pb}$ and $\mathrm{Zn}$ content in the plant material proved statistically insignificant. Nonetheless, the heavy metal levels in individual plants fluctuated depending on the dose and the kinds of the applied fertilizer.

Zn concentrations in the test plants, as compared with the other metal, were relatively big, which was due to a large amount of this metal supplied with the fertilizers but also to the highly active uptake of this metal by plants. $\mathrm{Zn}$ content ranged between 30.54 and $172.74 \mathrm{mg} \cdot \mathrm{kg}^{-1}$ and was not diversified between individual treatments, the variability coefficient for maize was $\mathrm{V}=30 \%$, for oat grass $\mathrm{V}=21 \%$ and for oat $\mathrm{V}=25 \%$. From among the test plants, the oat grass revealed the highest concentrations of $\mathrm{Zn}$, then maize and oat. Oat contained four times less $\mathrm{Zn}$ than the oat grass and 1.5 times less than maize. Among the treatments the highest content of $\mathrm{Zn}$ in plants was found on the treatment with a double dose (maize, oat) and single (oat grass) dose of industrial sludge (Tab.2). The least quantities of this metal were assessed in the plants obtained from farmyard manure and compost treatments. The increase in $\mathrm{Zn}$ content in maize and oat cultivated on a double dose of industrial sludge was $71 \%$ and $27 \%$ respectively, in comparison with the yields from the control. The $\mathrm{Zn}$ content in the oat grass diminished on average by $38 \%$ as a result of the applied fertilizers and the organic wastes and on a single dose of the farmyard manure and the double dose of compost even by $50 \%$ in relation to the control. The fertilizer effect of the farm- yard manure and the compost caused also a decline in $\mathrm{Zn}$ concentrations in maize and oat on single doses of these fertilizers, on average by $10 \%$ and $30 \%$, whereas on the double dose by $28 \%$ and $30 \%$ in comparison with the control.

$\mathrm{Cu}$ concentrations in plants ranged between 0.36 and $13.45 \mathrm{mg} \cdot \mathrm{kg}^{-1}$ (tab.2). Oat grass revealed a relatively high diversification in this metal content depending on the treatment $(\mathrm{V}=57 \%)$, then maize $(\mathrm{V}=48 \%)$ and oat $(\mathrm{V}=28 \%)$. Like in the case of $\mathrm{Zn}, \mathrm{Cu}$ concentrations increased in the direction of oat $<$ maize $<$ oat grass. The oat grass contained 6 times more $\mathrm{Cu}$ than oat and 4 times more than maize. Definitely the largest amounts of $\mathrm{Cu}$ were found in the yield from the treatments where a double dose of industrial sludge was applied, which resulted from high concentrations of this metal in this waste (Tab. $1,2)$. In comparison with the control the $\mathrm{Cu}$ level increased by $240 \%$ (oat grass), $131 \%$ (maize) and $5 \%$ (oat) under the influence of sludge. The lowest amounts of this element were registered in the yield from the compost treatments (maize) and the farmyard manure (the oat grass, oat).

In this experiment particular attention was paid to higher $\mathrm{Ni}$ concentrations in the municipal sewage sludge treatments and the industrial sludge (Tab.2). As reported by Filipek and Olek [2000] $\mathrm{Ni}$ in the municipal sludge occurs mainly in a soluble form: ionic and organic chelates easily absorbed by plants. This fact might have affected higher Ni concentrations in the test plants on these treatments. The Ni content in the plants fluctuated between 0.29 and $4.29 \mathrm{mg} \cdot \mathrm{kg}^{-1}$ (Tab.2). Maize revealed a relatively high diversification in $\mathrm{Ni}$ concentrations $(\mathrm{V}=51 \%)$ depending on the treatment, then oat $(\mathrm{V}=36 \%)$ and the oat grass $(\mathrm{V}=30 \%)$. Among the tested plants the oat grass was characterized by the highest $\mathrm{Ni}$ content, maize and oat placed next. The oat grass contained 4 times more $\mathrm{Ni}$ than maize and 6 times more than oat. Like in the case of $\mathrm{Zn}$ and $\mathrm{Cu}$, the highest content of nickel was registered in the plants from the industrial sludge and the municipal sludge treatment (oat grass, maize). On the treatment where a double dose of industrial sludge was used, the increase in the Ni content in comparison with the control, reached: $180 \%$ (maize), $91 \%$ (oat grass) and $98 \%$ (oat), respectively. This component contained the highest quantities of $\mathrm{Ni}$, hence its high concentration in the oat grass yield (Tab.1). The lowest level of the discussed metal was assessed in the yields of the plants from the farmyard manure treatment (both doses) and from the compost, except for the oat grass fertilized by a single dose of the 
Table 2. The experimental design and content of metals in plants

\begin{tabular}{|c|c|c|c|c|c|c|}
\hline \multirow[b]{2}{*}{ Treatments } & \multirow[b]{2}{*}{ Plant } & $\mathrm{Cd}$ & $\mathrm{Cu}$ & $\mathrm{Ni}$ & $\mathrm{Pb}$ & $\mathrm{Zn}$ \\
\hline & & \multicolumn{5}{|c|}{$\mathrm{mg} ? \mathrm{~kg}^{-1} \mathrm{~d} . \mathrm{m}$} \\
\hline \multirow{3}{*}{$\frac{1}{\text { Without fertilization }}$} & Maize & 1.02 & 1.45 & 0.56 & 0.66 & 34.51 \\
\hline & Oat grass & 3.67 & 3.97 & 2.24 & 6.74 & 172.64 \\
\hline & Oat fertilized & 0.72 & 1.32 & 0.43 & 0.72 & 30.54 \\
\hline \multirow{3}{*}{$\begin{array}{c}\text { II } \\
\mathrm{NPK}_{1}\end{array}$} & Maize & 0.68 & 1.06 & 0.99 & 0.87 & 39.85 \\
\hline & Oat grass & 1.90 & 3.45 & 2.93 & 4.32 & 118.10 \\
\hline & Oat fertilized & 0,42 & 0.80 & 0.47 & 0.69 & 22.62 \\
\hline \multirow{3}{*}{$\begin{array}{c}\text { III } \\
\mathrm{NPK}_{2}\end{array}$} & Maize & 0.53 & 1.04 & 1.02 & 0.99 & 38.96 \\
\hline & Oat grass & 1.49 & 3.43 & 2.91 & 3.53 & 102.04 \\
\hline & Oat fertilized & 0.27 & 0.61 & 0.38 & 0.57 & 17.41 \\
\hline \multirow{3}{*}{$\begin{array}{c}\mathrm{IV}^{*} \\
\text { Farmyard manure }\end{array}$} & Maize & 0.79 & 1.20 & 0.40 & 0.75 & 28.85 \\
\hline & Oat grass & 1.61 & 2.74 & 1.81 & 2.57 & 87.12 \\
\hline & Oat fertilized & 0.37 & 0.67 & 0.35 & 0.68 & 19.35 \\
\hline \multirow{3}{*}{$\begin{array}{c}\mathrm{V}^{*} \\
\text { Farmyard manure } \\
2\end{array}$} & Maize & 0.78 & 1.14 & 0.34 & 0.71 & 26.38 \\
\hline & Oat grass & 1.58 & 3.57 & 1.72 & 2.20 & 93.75 \\
\hline & Oat fertilized & 0.48 & 0.71 & 0.35 & 0.77 & 23.04 \\
\hline \multirow{3}{*}{$\begin{array}{c}\mathrm{Vl}^{*} \\
\text { Compos }_{1}\end{array}$} & Maize & 1.10 & 1.21 & 0.48 & 0.90 & 33.32 \\
\hline & Oat grass & 2.18 & 4.51 & 2.58 & 4.41 & 114.98 \\
\hline & Oat fertilized & 0.59 & 0.87 & 0.42 & 1.06 & 23.55 \\
\hline \multirow{3}{*}{$\begin{array}{c}\mathrm{VII}^{*} \\
\text { Compos }_{2}\end{array}$} & Maize & 0.91 & 1.04 & 0.41 & 0.81 & 22.96 \\
\hline & Oat grass & 1.69 & 4.03 & 1.86 & 3.39 & 87.15 \\
\hline & Oat fertilized & 0.49 & 0.90 & 0.29 & 0.86 & 19.60 \\
\hline \multirow{3}{*}{$\begin{array}{c}\text { VIII* } \\
\text { Municipal sludge }\end{array}$} & Maize & 1.07 & 1.39 & 0.69 & 0.68 & 38.08 \\
\hline & Oat grass & 2.38 & 6.83 & 3.23 & 6.30 & 112.34 \\
\hline & Oat fertilized & 0.57 & 0.90 & 0.60 & 1.08 & 28.47 \\
\hline \multirow{3}{*}{$\begin{array}{c}\text { IX* }^{*} \\
\text { Municipal sludge }\end{array}$} & Maize & 0.83 & 1.00 & 0.62 & 0.57 & 35.90 \\
\hline & Oat grass & 1.89 & 7.49 & 3.03 & 4.85 & 113.78 \\
\hline & Oat fertilized & 0.61 & 0.82 & 0.46 & 0.68 & 26.41 \\
\hline \multirow{3}{*}{$\begin{array}{c}X^{*} \\
\text { Industrial sludge }\end{array}$} & Maize & 1.40 & 1.99 & 1.13 & 0.69 & 52.89 \\
\hline & Oat grass & 1.86 & 8.69 & 3.80 & 5.39 & 121.00 \\
\hline & Oat fertilized & 0.57 & 1.11 & 0.72 & 0.85 & 33.38 \\
\hline \multirow{3}{*}{$\begin{array}{c}\mathrm{Xl}^{*} \\
\text { Industrial sludge }\end{array}$} & Maize & 1.07 & 3.35 & 1.57 & 0.88 & 61.39 \\
\hline & Oat grass & 1.10 & 13.45 & 4.29 & 5.47 & 115.63 \\
\hline & Oat fertilized & 0.59 & 1.38 & 0.84 & 0.72 & 39.30 \\
\hline $\operatorname{LSD}_{0,01}$ & \multicolumn{6}{|c|}{ I Fertilizer $-n$, II Dose $-n, I * \|-n$} \\
\hline
\end{tabular}

${ }^{1}$ dose for $1^{\text {st }}$ fertilization level, ${ }^{2}$ dose for $2^{\text {nd }}$ fertilization level, ${ }^{*}$ Use in the first year of the experiment, $n-$ differences not significant.

compost. The farmyard manure used for the experiment caused a decrease in the $\mathrm{Ni}$ content in relation to the control, on average by $34 \%$ (maize), $21 \%$ (oat grass) and $18 \%$ (oat).

The $\mathrm{Pb}$ content in the plant yield ranged between 0.57 and $6.74 \mathrm{mg} \cdot \mathrm{kg}^{-1}$, variability coefficient for maize was $\mathrm{V}=16 \%$, for oat grass $\mathrm{V}=32 \%$ and for oat $\mathrm{V}=20 \%$. Like in the case of the above mentioned metals, the highest $\mathrm{Pb}$ concentrations were found in the oat grass, whereas in maize and oat this metal contents were comparable (Tab.2). Oat grass contained about 6 times less $\mathrm{Pb}$ in comparison with maize and oat. The highest amount of $\mathrm{Pb}$ in maize yields, in comparison with the control, were registered on NPK treatments (by 40\%) and both doses of compost (by $30 \%$ ). In the oat grass the $\mathrm{Pb}$ content in all the treatments was smaller than on the control on average by $37 \%$ and on the farmyard manure treatment even by $65 \%$. On the other hand, a comparison of the treatments with each other shows the highest $\mathrm{Pb}$ content in oat grass on treatments with a single dose of the municipal sludge. In oat much higher amounts of $\mathrm{Pb}$ were detected on the treatments with the compost and the single dose of municipal sludge. In comparison with the control, the $\mathrm{Pb}$ level raised on average by $47 \%$ under the influence of the above mentioned compost and the municipal sludge. Accumulation of considerable quantities of $\mathrm{Pb}$ under the influence of the sewage sludge fertilization was also confirmed by other authors [Filipek-Mazur et al 2000].

The Cd content in plants, depending on the treatment, fluctuated from 0.27 to $3.67 \mathrm{mg} \cdot \mathrm{kg}^{-1}$, the variability coefficient for maize was $\mathrm{V}=26 \%$, for the oat grass $\mathrm{V}=35 \%$ and for oat $\mathrm{V}=25 \%$ (tab.2). Like in the case of $\mathrm{Zn}, \mathrm{Cu}$ and $\mathrm{Ni}$, the content of $\mathrm{Cd}$ was diminishing in the direction of the oat grass $>$ maize $>$ oat. The oat grass contained on average twice more $\mathrm{Cd}$ than maize and almost four times more than oat. The highest content of this metal was noted in the industrial sludge treatments (maize) and the municipal sludge treatment (oat grass and oat).On industrial sludge treatment the increase in $\mathrm{Cd}$ in comparison with the control was $21 \%$ (maize). For the oat grass and oat the applied fertilizers and wastes led to a decrease in Cd concentrations on average by $52 \%$ (oat grass) and $44 \%$ (oat) in relation to the control. As a result of the farmyard manure activity, the $\mathrm{Cd}$ level in the discussed plants was on average $23 \%$ lower (maize), $57 \%$ (oat grass) and $85 \%$ (oat) than in the control.

The quantities of the elements absorbed by plants depended on the amount of the yield and the content of individual metals. The summary uptake of heavy metals per pot ranged between 0.26 and $4.59 \mathrm{mg} \mathrm{Zn}, 0.10$ $559.61 \mu \mathrm{g} \mathrm{Cu}, 3.76-178.72 \mu \mathrm{g} \mathrm{Ni}, 6.38-227.85 \mu \mathrm{g} \mathrm{Pb}$ and $4.04-85.73 \mu \mathrm{g} \mathrm{Cd} \cdot$ pot $^{-1}$ (Fig.1). 

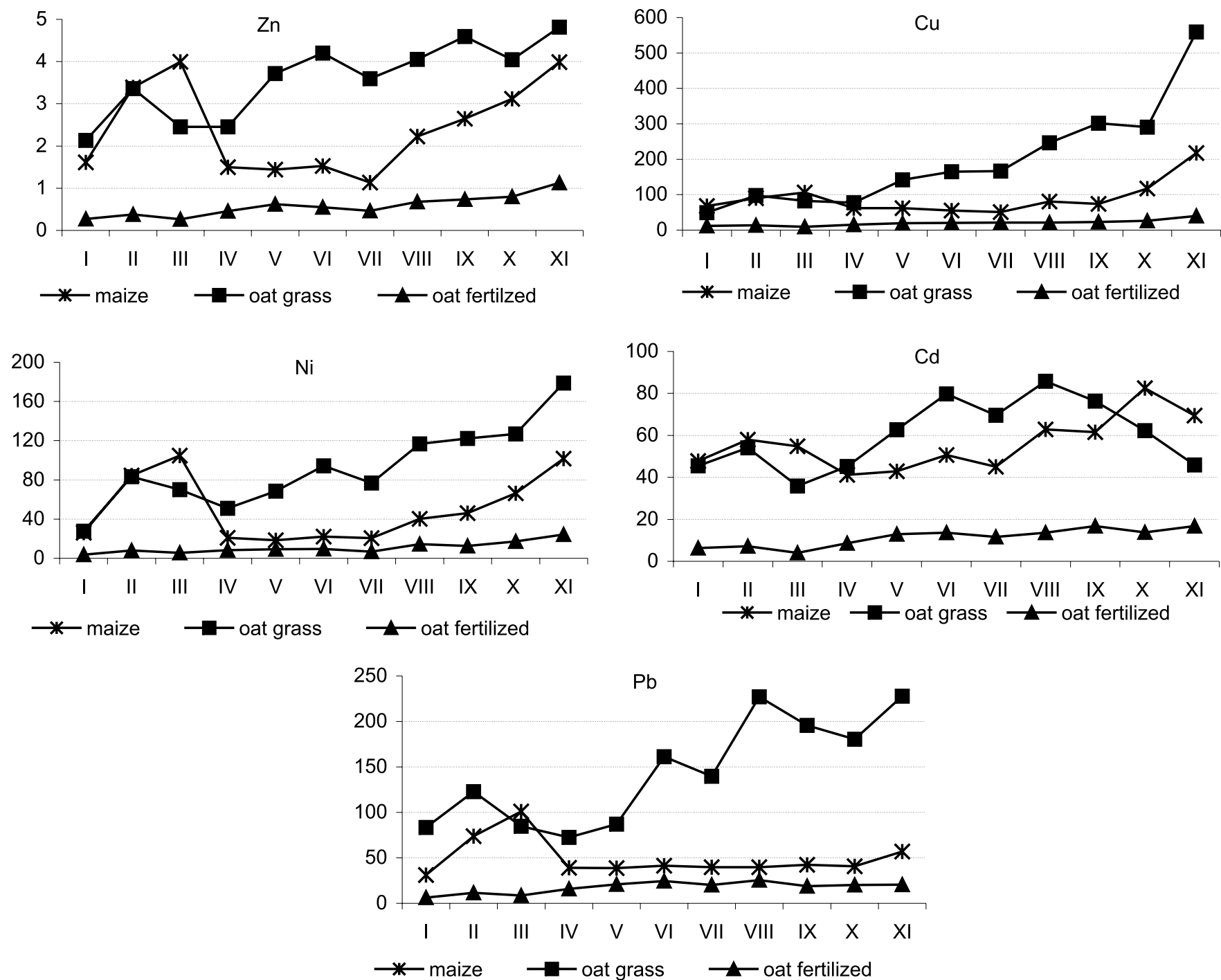

Figure 1. Uptake of $\mathrm{Zn}\left(\mathrm{mg} \cdot \operatorname{pot}^{-1}\right), \mathrm{Cu}, \mathrm{Ni}, \mathrm{Cd}$ and $\mathrm{Pb}\left(\mu \mathrm{g} \cdot\right.$ pot $\left.^{-1}\right)$ by plants.

Considering the shares of individual plants in the total uptake it was found that the highest metal removal was with the oat grass yield, then the maize yield, whereas the least was removed with the oat yield. The oat grass absorbed $55 \% \mathrm{Zn}, 64 \% \mathrm{Cu}, 60 \% \mathrm{Ni}, 68 \% \mathrm{~Pb}$ and $47 \% \mathrm{Cd}$ of the total amount of heavy metals. The maize and oat yield removed: $37 \%$ and $9 \% \mathrm{Zn}, 29 \%$ and $7 \% \mathrm{Cu}, 33 \%$ and $7 \%$ $\mathrm{Ni}, 23 \%$ and $8 \% \mathrm{~Pb}$ and $44 \%$ and $9 \% \mathrm{Cd}$, respectively. A relatively considerable diversification in individual metals' removal was characteristic of maize $(\mathrm{Zn} \mathrm{V}=44 \%, \mathrm{Cu}$ $\mathrm{V}=53 \%$, $\mathrm{Ni} \mathrm{V}=67 \%, \mathrm{~Pb} \mathrm{~V}=42 \%$ and $\mathrm{Cd} \mathrm{V}=22 \%$ ), then oat $(\mathrm{Zn} \mathrm{V}=44 \%, \mathrm{Cu} \mathrm{V}=41 \%$, Ni V=54\%, $\mathrm{Pb} \mathrm{V}=36 \%$, and $\mathrm{Cd} \mathrm{V=37 \% ).} \mathrm{The} \mathrm{heavy} \mathrm{metal} \mathrm{removal} \mathrm{with} \mathrm{the} \mathrm{oat}$ grass was not significantly diversified, as evidenced by the computed variability coefficients, $\mathrm{Zn} \mathrm{V}=25 \%, \mathrm{Cu} \mathrm{V}=18 \%$, $\mathrm{Ni} \mathrm{V}=29 \%$ and $\mathrm{Cd} \mathrm{V}=27 \%$ respectively, except for lead $(\mathrm{V}=41 \%)$. The analysis of heavy metal removal depending on the kind and dose of the applied fertilization shows the highest $\mathrm{Zn}, \mathrm{Cu}, \mathrm{Ni}$ and $\mathrm{Pb}$ removal with the plant yield on the treatments where a double dose of the industrial sludge was used. The summary increase in $\mathrm{Zn}, \mathrm{Cu}, \mathrm{Ni}$ and $\mathrm{Pb}$ uptake by the plants on this treatment in relation to the control was: $147 \%, 535 \%, 428 \%$ and $153 \%$, respectively. For cadmium the highest removal with the yield was observed on a single dose of the municipal sludge. In comparison with the control the $\mathrm{Cd}$ removal with the yield raised by $63 \%$. The smallest removal of the analyzed metals was observed on a single dose of the farmyard manure. On this treatment the removal of investigated metals was as follows: $\mathrm{Zn} \mathrm{1.7;} \mathrm{Cu}$ 5.3; $\mathrm{Ni} 2.6$; $\mathrm{Pb} 1.9$ and Ni 1.7 times less than on the treatment where the highest removal was detected. The summary removal of individual metals with the plant yield, depending on the treatment may be presented for the individual metals in the following diminishing order:

$-\mathrm{Zn}$ : the industrial sewage sludge $>$ NPK $>$ the municipal sludge $>$ the compost $>$ the farmyard manure,

$-\mathrm{Cu}$ : the industrial sewage sludge $>$ the municipal sewage sludge $>$ the compost $>$ NPK $>$ the farmyard manure,

- Ni: the industrial sewage sludge $>$ the municipal sewage sludge ? NPK $>$ the compost $>$ the farmyard manure,

$-\mathrm{Pb}$ and $\mathrm{Cd}$ : the municipal sewage sludge $>$ the industrial sewage sludge $>$ the compost $>$ NPK $>$ the farmyard manure.

\section{DISCUSSION}

It is commonly known that among agrotechnical factors mineral and organic fertilization mainly determines plant's chemical composition [Mazur 1999, 2002]. Both the mineral and the organic fertilization (farmyard manure, compost, sewage sludges) used in the 3-year experiment allowed for an assessment of the effect of the selected 
fertilizers and the organic wastes on the heavy metal content in various plant species. The use of organic wastes (compost, sewage sludges) for plant fertilization may either positively affect the plant and the soil chemical composition or cause an excessive accumulation of heavy metals in plants. Therefore, application of the above mentioned fertilizer components must be preceded by the analyses of their chemical composition [Rozporządzenie 2002, Norma Branżowa 1989]. Moreover, the waste influence on the plant chemical composition and the physicochemical soil properties should be analyzed. In the presented experiment the fertilizer effect of urban and industrial sewage sludges caused a relatively high concentrations of heavy metals and their removal with the yield of the test plants. Curyło [2000] obtained similar results while studying the chemical composition and the fertilizer value of coagulative sludges from the water treatment plant. The applied sludge contained on average 20 times more $\mathrm{Zn}, 140 \mathrm{Cu}$, $5.6 \mathrm{Ni}, 7.5 \mathrm{~Pb}$ and $1.7 \mathrm{Cd}$ in comparison with the soil used for the experiment. As a result their uptake by plants increased. The fertilizer effect of the farmyard manure caused a decline in the concentrations of $\mathrm{Zn}, \mathrm{Ni}$ and $\mathrm{Cd}$ in the test plants in comparison with the control, while for $\mathrm{Cu}$ and $\mathrm{Pb}$ levels were the lowest among the treatments. The plants tested in the experiment differed with their heavy metal concentrations and it is a well known fact from literature that plants are characterized by various ability for absorption and tolerance to high concentrations of heavy metals, dependant on species [Wójcik, Tunkendorf 1995, Kabata-Pendias and Pendias 1999]. In the presented experiment the oat grass revealed the highest content and the uptake of metals, maize and oat placed next. It results from the potential ability of grasses for high accumulation of heavy metals in roots and their use for the phytostabilization of heavy metals in the soil [Góral 2001, Jasiewicz et al 2006]. Selection of maize, oat grass and oat as the test plants was also caused by a potential utilization of the obtained yield for animal feeds. From the agronomic perspective the application of organic wastes has a major environmental and ecological importance and allows limiting the consumption of mineral fertilizers, whose effects are less beneficial for the environment than the organic fertilizer effects [Mazur 1996, Siuta, Wasiak 2001].

\section{CONCLUSIONS}

1. Metal concentrations in the test plants were diminishing in the following direction: oat grass $>$ maize $>$ oat.

2. In comparison with other metals, the plants contained the greatest amounts of $\mathrm{Zn}$. The levels of metals looked as follows: $\mathrm{Zn}>\mathrm{Cu}>\mathrm{Pb}>\mathrm{Ni}>\mathrm{Cd}$.

3. Relatively highest concentrations of $\mathrm{Zn}, \mathrm{Cu}, \mathrm{Ni}, \mathrm{Pb}$ and $\mathrm{Cd}$ in plants were registered on industrial sludge treatments, whereas $\mathrm{Pb}$ and $\mathrm{Cd}$ on treatments with urban sewage sludge.

4. The lowest concentrations of the analyzed heavy metals were assessed in the plants fertilized with the farmyard manure and the compost $(\mathrm{Zn}, \mathrm{Cu})$. The fertilizer activity of the farmyard manure caused a decline in the $\mathrm{Zn}, \mathrm{Ni}$ and $\mathrm{Cd}$ content in plants in relation to the control.

5. Among the tested plants the highest quantities of $\mathrm{Zn}$, $\mathrm{Cu}, \mathrm{Ni}, \mathrm{Pb}$ and $\mathrm{Cd}$ were removed with the yield of the oat grass, then maize and oat. Of the total amount of heavy metals the oat grass absorbed $55 \% \mathrm{Zn}, 64 \% \mathrm{Cu}, 60 \% \mathrm{Ni}$, $68 \% \mathrm{~Pb}$ and $47 \% \mathrm{Cd}$.
6. The highest uptake of $\mathrm{Zn}, \mathrm{Cu}, \mathrm{Ni}$ and $\mathrm{Pb}$ by plants was registered on a double dose of the industrial sludge and $\mathrm{Cd}$ on a single dose of the municipal sludge.

\section{LITERATURE CITED}

(1) Baran S., Wójcikowska-Kapusta A., Jaworska B.: Przydatność wikliny do sanitacji gleb zanieczyszczonych miedzia i ołowiem. Zesz. Probl. PNR, 477, 2001, 187 - 193.

(2) Chwastowska J., Skalmowski K., Sterlińska E., Wolska K., Skwara W.: Metale ciężkie i formy ich występowania w kompostach $\mathrm{z}$ odpadów miejskich uzyskiwanych według technologii Dano w Warszawie. Arch. Ochr. Srod., 1993, 3 $-4,251-259$.

(3) Curyło T.: Wstępna ocena osadu chemicznego i wartości nawozowej osadów koagulacyjnych ze stacji uzdatniania wody. Zesz. Prob. PNR, 2000, 472, 137 - 148.

(4) Czekała J.: Osady ściekowe źródłem materii organicznej i składników pokarmowych. Fol. Univ. Agric. Stetin. 200, Agriculture, 1999, 77, 33 - 38.

(5) Filipek T., Olek J.: Akumulacja i pobiernie metali niklu przez rośliny testowe nawadniane oczyszczonymi ściekami komunalnymi Zesz. Prob. PNR, 2000, 427, 235 - 240.

(6) Filipek-Mazur B., Mazur K., Gondek K.: Wpływ nawożenia wermikompostem na plon i rozmieszczenie metali ciężkich w kukurydzy. Zesz. Prob. PNR, 2000, 472, 225 - 233.

(7) Gambuś F., Wieczorek J.: Skład chemiczny i wartość nawozowa kompostów i wermikompostów z osadów ściekowych nadmiernie zanieczyszczonych metalami ciężkimi. Zesz. Prob. PNR, 1999, 467, 513 - 520.

(8) Góral S., Roślinność zielna w ochronie i rekultywacji gruntów. Inżyn. Ekolg., 2001, 3, 161 - 178.

(9) Grzywnowicz I., Strutyński J.: Zmiany niektórych właściwości chemicznych gleby po zastosowaniu osadów ściekowych do celów nawozowych. Zesz. Probl. PNR, 1999, 467, 299 - 306.

(10) Jasiewicz Cz., Antonkiewicz J., Baran A.: Influence of organic fertilization on content of heavy metals in tall oat grass. Ecol. Chem. and Eng., 2006, 13, 915 - 924.

(11) Jasiewicz Cz., Antonkiewicz J.: Wpływ dawki i rodzaju nawozu na zawartość azotu w kukurydzy. Monografie Wszechnicy Mazurskiej w Olecku, 2005, 143 - 152.

(12) Kabata-Pendias A., Pendias H.: Biogeochemia pierwiastków śladowych. Wyd. Nauk. PWN, Warszawa 1999, 397.

(13) Kabata-Pendias A., Piotrowska M., Motowicka-Terelak T., Maliszewska-Kordybach T., Filipiak K., Krakowiak A., Pietruch Cz.: Podstawy oceny chemicznego zanieczyszczenia gleb - metale ciężkie, siarka i WWA. Państwowa Inspekcja Ochrony Środowiska. Bibliot. Monit. Środ., Warszawa, 1995, 41.

(14) Mazur T.: Rolnicze i ekologiczne znaczenie nawożenia organicznego i mineralnego. Zesz. Probl. PNR, 1999, 467, $151-157$.

(15) Mazur T.: Rozważania o wartości nawozowej osadów ściekowych. Zesz. Prob. PNR, 1996, 437, 13 - 21.

(16) Mazur T.: Rozważania o wartości nawozowej odpadów organicznych. Acta Agrophysica, 2002, 70, 257 - 263.

(17) Norma Branżowa, Unieszkodliwianie odpadów miejskich. Kompost z odpadów miejskich. 1989, BN-89/9103-09.

(18) Ostrowska A., Gawliński S., Szczubiałka Z.: Metody analizy i oceny właściwości gleb i roślin. Wyd. IOŚ, Warszawa, $1991,334$.

(19) Rozporządzenie Ministra Środowiska z dnia 1 sierpnia 2002 r. w sprawie komunalnych osadów ściekowych. Dz. U. RP, Nr 134, Poz. 1140.

(20) Siuta J., Wasiak G.: Zasady wykorzystania osadów ściekowych na cele nie przemysłowe (przyrodnicze). Inżyn. Ekolog., 2001, 3, 13 - 42.

(21) Wójcik A., Tunkendrof A.: Strategia unikania stresu w odporności na metale ciężkie. Wiad. Bot., 1995, 39(3/4), 33 - 40. 